\title{
Will crypto-nuclear powers come clean?
}

Next week's crucial meeting of the parties to the Non-Proliferation Treaty cannot put off some consideration of what will happen to countries believed to have nuclear weapons up their sleeves.

WHEN is a country a nuclear power? "When it has nuclear weapons, of course!" So what is to be made of Israel, which has operated a reactor at Davona in the Negev Desert since the early 1960s, which has declined to sign the Nuclear NonProliferation Treaty (NPT), which has jailed for life a technician who told a British newspaper of an underground plutonium factory in the desert, but which seems not to have carried out a nuclear test? Or of India, which conducted an underground nuclear explosion in 1974, but which insisted that its interests were exclusively in peaceful uses of nuclear explosives, which has also declined to sign the NPT, but which has not carried out a nuclear test for 20 years?

The conventional description is that they are 'cryptic' nuclear powers; they have not advertised their possession of nuclear weapons, but their neighbours must in prudence behave as if they had at least modest numbers. (Pakistan is known to have responded to India's status with at least a laboratory-scale programme of development in plutoniumseparation. Iraq seems to have responded on behalf of Israel's Muslim neighbours with a nuclear development programme, now dismantled; Iran may have taken over where Iraq had to leave off.) It is to the credit of the President of Egypt, Hosni Mubarak, that he has raised the issue of the crypto-nuclear powers on the eve of the fourth and crucial review conference of the NPT in Geneva next week.

This meeting is crucial because the NPT will lapse this year unless the parties to the treaty collectively agree that it should continue. Against the odds, and despite the tardiness with which the nuclear powers recognized that this longstanding date on their calendars would come round, the prospects for the conference are more cheerful than they might have been. It seems assured that there will be enough votes to keep the NPT alive; the outstanding issue is whether, like the version ratified in 1970 , it will be a fixed-

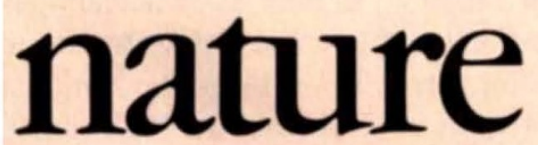

\section{New} address

From 18 April 1995 our address will be: Porters South Crinan Street London N1 9SQ

Tel: $+44(0) 1718334000$

Fax: $+44(0) 1718434596 / 7$ term treaty. This has been primarily accomplished by the willingness of the principal nuclear powers to negotiate among themselves a treaty to ban the testing of nuclear weapons for the rest of time. The promised negotiations may yet hit unexpected snags, but the promise is a dramatic capstone on the network of bilateral arms control treaties between Russia and the United States negotiated in the past few years. If it had been made five years ago, a great deal of trouble would have been saved.

And now, of course, there are the crypto-nuclear powers to be brought within the fold. Egypt's dialogue with Israel is central to this task. Israel has a strong case for being a nuclear power. For much of its history, its neighbours have denied its right to exist. What better means of deterring a concerted attack than implicitly to threaten enemies' cities with destruction? Even what is now called the Middle East peace process has not ended that sad state of affairs. The delicacy of Egypt's approach to Israel shows an understanding of this point, but there is no obvious solution in sight. Formal external military guarantees would not suffice. But on present form, it will be a long time before the peace process has gone far enough to be convincing. And while a solution of the problem would be to admit Israel to the NPT with the status of a nuclear power, that would simply invite North Korea to apply for membership in that guise.

In the end, the only solution is a general understanding in the United Nations that the manufacture of nuclear weapons is unacceptable, inviting all necessary sanctions to bring it to a halt. But the established nuclear powers (China included) will have to go much further than the promise of a test-ban before that is feasible. A verifiable cut-off of the production of fissile material for military purposes is the next step. It would be best that the NPT should not be made a perpetual treaty at least until that has been achieved.

\section{Give CSIRO a rest!}

Australia's research organization needs a period without formal inquiry into its ways of working.

AUSTRALIA's delight in sports of all kinds sometimes gets the better of it. The sport of inquiring into the condition of the country's chief research organization, the Commonwealth Industrial and Scientific Research Organization (CSIRO), of making recommendations and causing a little administra- 